\title{
sciendo
}

Transport and Telecommunication, 2019, volume 20, no. 1, 82-91

Transport and Telecommunication Institute, Lomonosova 1, Riga, LV-1019, Latvia

DOI 10.2478/ttj-2019-0008

\section{GROWING TRADE, BUT SLOWING UNITIZED SHORT SEA SHIPPING: ANALYSING FINLAND AND GERMANY}

\author{
Olli-Pekka Hilmola ${ }^{1}$, Andres Tolli ${ }^{2}$ \\ ${ }^{1}$ LUT University Kouvola Unit, Prikaatintie 9 , \\ FIN-45100 Kouvola, Finland, and \\ TalTech, Estonian Maritime Academy, Kopli 101, 11712 Tallinn, Estonia \\ olli-pekka.hilmola@lut.fi \\ ${ }^{2}$ TalTech, Estonian Maritime Academy, Kopli 101, 11712 Tallinn, Estonia, \\ andres.tolli@taltech.ee
}

In this research is being analyzed trade relationship and unitized maritime cargo between Germany and Finland. Focus in longitudinal analysis (2001-2017) is on maritime transport, and particularly within the development of different Finnish sea ports in unitized German cargo handling. Trade has been significantly growing over the decades and is on record highs in the most recent year (2017). Germany has also become largest trade partner of Finland. However, after 2003 trade bas been on growing deficit path, and is currently more than one billion deficits for Finland. Rather surprisingly, unitized cargo flows are not growing as much as trade suggests. Still best years are from time before Global Financial Crisis (GFC). Some sea ports in Southwest of Finland have been on clear declining path, while largest sea ports could be considered as somehow sustaining in volumes. Growth is on some smaller and mid-sized sea ports, which have direct regional need for German trade. Hinterland transports through Baltic States must have taken share of direct maritime transports from Finnish sea ports.

Keywords: Unitized cargo, Finland, Germany, economic development, sulphur regulation

\section{Introduction}

In global scale, German exports have dominated the world trade together with China (e.g. Hilmola, 2014), and German trade surpluses have persisted for decades. Of course, some important energy exporters are having significant long-term surpluses as well (such as Saudi Arabia and Russia), but two earlier mentioned countries have built their export performance with manufacturing competence and superior products in the eyes of customers. Germany is also dominating trade in Europe, and it has been said that euro currency is too weak for this country as it provides too high competitive advantage as compared to other euro countries (e.g. Rickards, 2012; Varoufakis, 2016). Challenge is not only with European Union, but also with other developed countries, such like USA (its German trade deficit in 2017 was 64 bill. USD). As a remedy has been offered more imports and higher domestic spending (Ellyatt, 2018). In 2017, some sort of small progress was made as trade surpluses of Germany declined first time since 2009 (Reuters, 2018a).

In the aftermath of European debt crisis, it has been demanded by different parties that Germany should increase its salaries substantially and "give" opportunity and room for other euro currency countries to grow (Stiglitz, 2018).

Heilmann and Wolff (2018) suggest that now great German exports to the United States and China should have shrinking role in the future. Focus should be instead in European based growth. Quite significant number of euro zone members are having positive current account - in Germany this is $8 \%$ of GDP (in 2017).

Besides foreign trade performance, Germany is dominating also logistics sector. Some of the largest sea ports of Europe are located in its shores, and its domestic freight market is the biggest in the European Union in both railways and trucking. In airline rankings, Lufthansa has been competing head to head with Ryanair from the title of the biggest air passenger transporter in Europe (Reuters, 2018b). In addition, global third party logistics companies such as DHL (Deutsche Post) and DB-Schenker are German based. DHL had global revenues of 60.4 bill. EUR in 2017, and DB-Schenker respectively 42.7 
bill. EUR (DHL, 2018; DB-Schenker, 2018). DHL is partially owned by government, while DB-Schenker is still entirely under governmental ownership.

In this research is examined maritime trade flows in unitized cargo segment between Germany and Finland. Both national and EU level second-hand statistics are used to analyse development overall and at sea port basis. Time period of the study is 2001-2017 (in some cases statistics out of late 90's are taken into account). Both of the countries are high-income economies, which could be considered to be advanced in technological and economic terms. Trade of these countries has long tradition, and it has for long time had as important component short sea shipping through Baltic (and in some situations North) Sea. As competing routes to sea based one have been those utilizing less shipping, and more hinterland transports such as trucks. Currently it is popular to transport from Finland to Europe items through Baltic States (Hilmola, 2019), but in earlier decades Sweden served as such transit route. Increasing environmental demands have also played their part as in many countries there exist road usage payments (e.g. Germany and Poland), and in others they have implemented Vignette based systems (e.g. all Baltic States and Sweden). Also shipping has been faced by environmental demands as sulphur regulation was implemented in years 2010 and 2015 within Baltic Sea, and it has resulted to situation, where ships need to use higher priced, but only $0.1 \%$ sulphur content diesel (IMO, 2018). Other demands are on the horizon, like Nitrogen ban at Baltic Sea (after 2021 all new ships should not emit at all), and $\mathrm{CO}_{2}$ reduction programme of entire transportation sector in European Union (Hilmola, 2019). Therefore, the purpose of this study is to examine mostly at sea port level, how these numerous changes have affected sea port handling of unitized German cargo in Finland. There have been factors limiting sea port handling competitiveness, and also competition between sea ports have surely existed. As a primary objective is to identify, which sea ports have grew and/or sustained in this particular German sub-market, and as opposite, which have lost their volumes.

This research is structured as follows: In Section 2 is analysed macro-economic development in Germany and Finland, together with trade performance of this trade-pair with each other. Thereafter, in Section 3 follows analysis of unitized (semi-trailers with or without truck, containers and other intermodal units) maritime cargo flows between Germany and Finland (analysis is overall and at sea port level). In Section 4, study is concluded, and further research avenues are being proposed.

\section{Macro-Economic Background in Finnish and German Unitized Maritime Flows}

Ordinary perception of Finnish and German economies is that they are both advanced and strongly growing. This is, however, only partially valid. Both are of course having high GDP levels, but in Finland, best growth was period before Global Financial Crisis (GFC), as GDP growth in 20002008 on the average was more than $3 \%$. Industrial sector (forest industry, es pecially the demand for produced paper), foreign trade (export), high cost (salaries and currency) and company specific (e.g., Nokia and telecommunications sector overall) problems led to the situation in 2010-2017 that Finnish growth was only barely on the average one percent. Domestic market was also having growth challenges as people were ageing and retiring as well as debt based economic model did not anymore provide opportunity for further consumption. German story is similar, but in GDP development te rms opposite. Due to integration of East Germany, stagnant (or even decreasing) salaries and partially lost competitiveness in industrial sectors, Germany was in sluggish growth mode during 2000-2008 (e.g. Lapavitsas et al., 2012), only half what Finland had in this time. German domestic consumption market was also hurt in this period. However, in the latter period of 2010-2017 everything has been better. Average annual growth is somewhat above $2 \%$. This is not high, but it is good performance in debtridden and ageing Europe. Both countries experienced significant decline in GDP during 2009, however, in Finland this downfall was bigger.

Unlike many other European countries, trade of Germany with Finland has been on consistent growth mode for two decades time (Fig. 2). From year 1998 to 2017, overall trade in euros has doubled (growth of $101.2 \%$ ). Trade has already in 2015 matched the level of pre-crisis time, year 2008. In 2017, German trade was $17.9 \%$ higher than in year 2008. Typically, German trade has competed with Russia from the most important trade country position with Finland, but in recent years' it has become clear that Germany is the largest trade partner (actually in years 2014-2017 it has done so). Russia was such in years 2008-2013, however, GFC, followed by Ukrainian dispute with economic sanctions, and oil price decline in 2014-2016, it is clear from Figure 2 that eastern trade has faced its difficulties. Actually, in the most recent years (2015-2017) Russia's position has dropped to the third most important trade partner as overall trade was continuously shrinking, and Swedish trade was able slightly grow (and sustained its absolute level). 
It was a fact of growth in container handling at sea ports for longer period of time that every-time GDP grew, so did container handling. Actually, growth in latter was in the best period of time several times higher than GDP growth. In years of 1998 to 2007 global GDP grew $3 \%$ as container trade was showing growth of $10 \%$ - somewhat above three times economic growth (Liu, 2010; Rashidi and Tsang, 2016). Similar situation took place in Baltic Sea area in 2000-2008, when GDP growth rate was much lower than container market growth. However, in recent years, globally and locally, growth effects have slowed down and relationship has weakened (United Nations, 2018). Another unitized cargo segment in Europe that of RoRo is quite different from containers. It is direct, lead time and value driven network, where transshipments do not take place (De Langen et al., 2016).

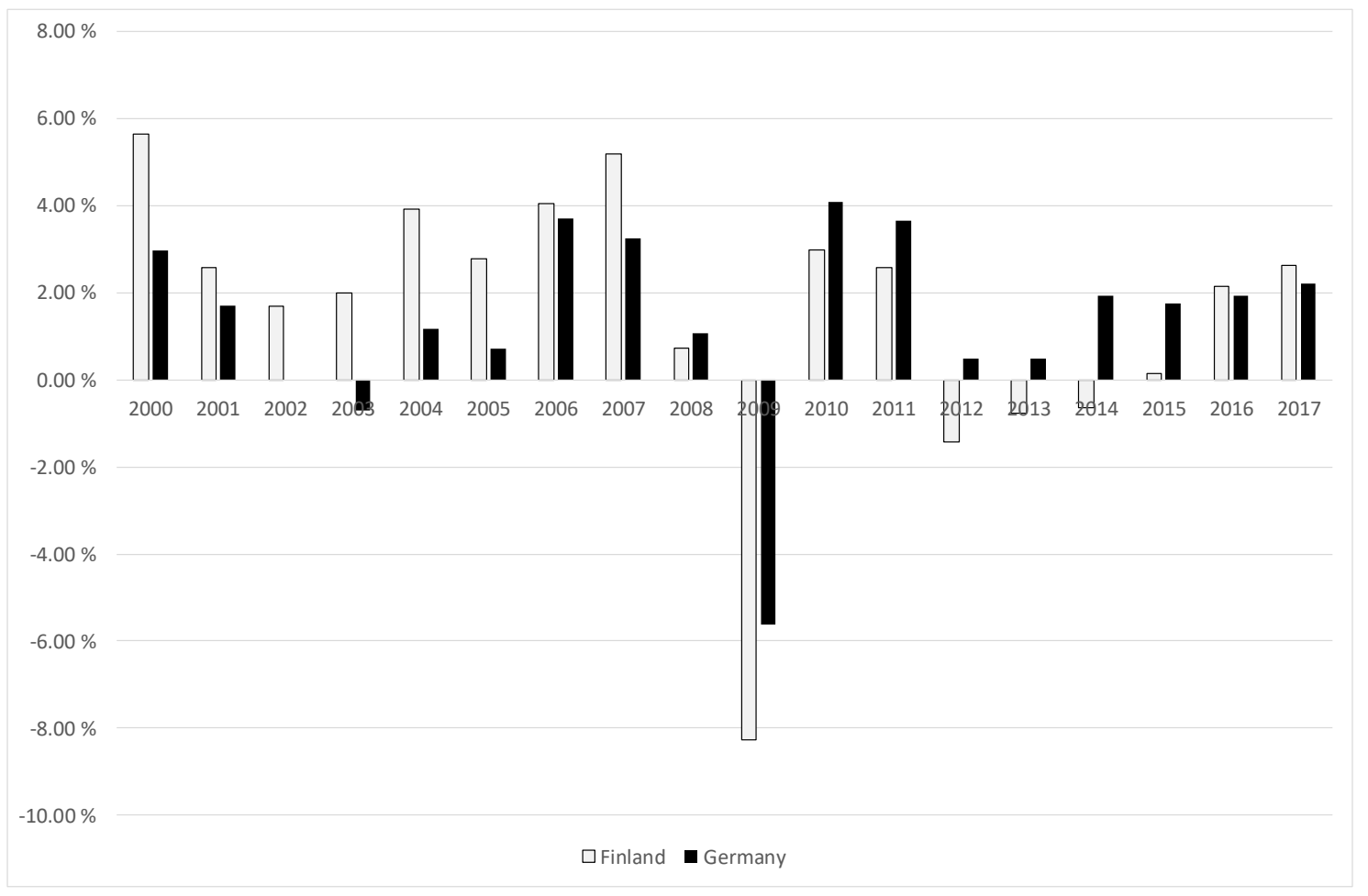

Figure 1. Annual change (\%) of GDP within Finland and Germany during the period of 2000-2017 (GDP values in USD). Source (data): World Bank (2018)

It was a fact of growth in container handling at sea ports for longer period of time that every-time GDP grew, so did container handling. Actually, growth in latter was in the best period of time several times higher than GDP growth. In years of 1998 to 2007 global GDP grew $3 \%$ as container trade was showing growth of $10 \%$ - somewhat above three times economic growth (Liu, 2010; Rashidi and Tsang, 2016). Similar situation took place in Baltic Sea area in 2000-2008, when GDP growth rate was much lower than container market growth. However, in recent years, globally and locally, growth effects have slowed down and relationship has weakened (United Nations, 2018). Another unitized cargo segment in Europe that of RoRo is quite different from containers. It is direct, lead time and value driven network, where transshipments do not take place (De Langen et al., 2016).

Nowadays Finnish foreign trade is having huge challenge to compete with larger countries such as Germany and Russia. Annual trade account deficit are significant, and since 2003, German trade has been on constant annual deficit. Depending on year, it is between one or two billion euros. Cumulatively in the period of 2003-2017 trade deficit with Germany has been 20 bill. euros. This is large sum of money, however, Russian trade has been even in larger deficit: In years 1999-2017 total cumulative deficit is 49.7 bill. euros. These two larger countries have their differences. In German trade, deficit will mean that there is possibility for more imports to Finland using unitized transport means rather than high volume exports (this also in weight), however, most typically this is not the case. German exports are just higher priced products, and Finnish exports nowadays again lower priced goods. In weight terms, Finnish export to Germany is much higher in unitized cargo terms than German imports to Finland. This is the situation in overall trade too (taking into account all bulk classes). Russian trade in turn differs from German in a way 
that most of its export volume is from energy products, which do have own specialized supply chains. Therefore, in unitized terms export from Finland to Russia has been bigger than other way around - in most recent years this has changed a bit to better balance as raw materials are also increasingly containerized (as transported from Russia to Finland).

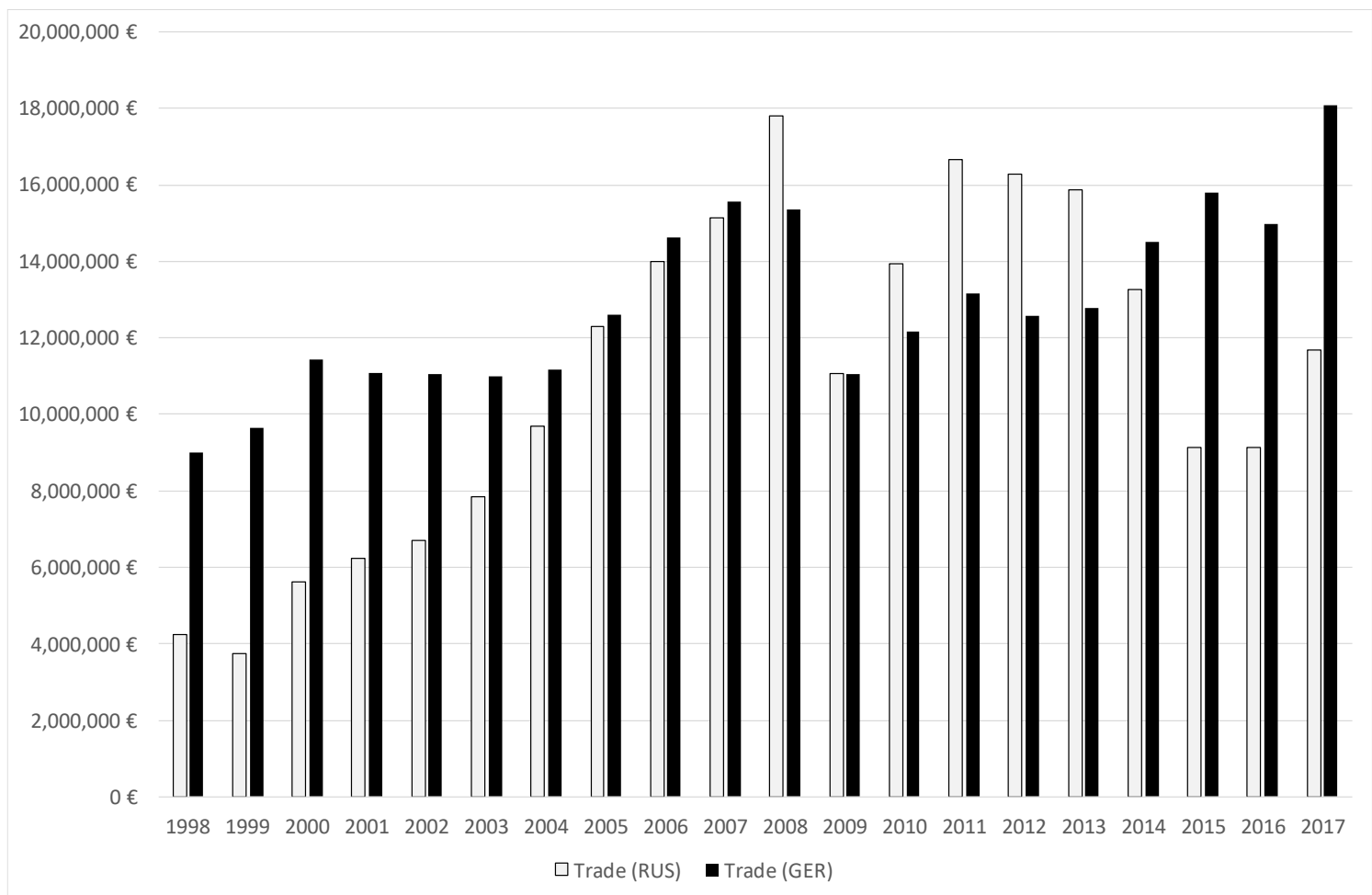

Figure 2. Overall trade of Finland (in '000 EUR) with Russia (RUS) and Germany (GER) during the period of 1998-2017. Source (data): Finnish Customs (2018)

\section{Unitized Maritime Flows Between Finland and Germany}

Most often, it is so that trade numbers in currencies could show progress and clear upwards trend, however, unitized cargo does not necessarily follow this. Reasons are numerous. First one is related to general time value of money (inflation). Even if Finnish-German trade has grown in recent year 2017 so much that it is clearly above year 2008, it has not grown if we assume even moderate $2 \%$ inflation on prices in this time period. If prices have increased $3 \%$ p.a., then current level of trade is well below, what it was in 2008. Another reason is the possible rerouting of cargo through other competing routes. In the case of Finland, one of such routes has been very short-sea connection from Helsinki to Tallinn, and from there on with truck to Poland, Germany or somewhere else in Central and Eastern Europe. This shift has been caused by increased sea transportation costs due to sulphur regulation and higher priced maritime diesel oils (or using scrubbers, million euro investment on single ship; Lindstad et al., 2017). Third reason is the competition of major sea container hub, and therefore Finnish export containers do not end up to German sea ports, but e.g. to Rotterdam or Antwerp (from where exports are transported to final destination by truck).

Based on De Langen et al. (2016) most of the highest ranked European sea ports do have significant RoRo volumes. There are some exceptions on this, like ports of Antwerp, Rotterdam, HaminaKotka, and St. Petersburg. First two mentioned have just so high container handling volume that RoRo volumes are not able to become so significant in statistics (De Langen et al., 2016). Two latter sea ports are just too remote, and favour more containers and bulk shipping rather than RoRo. 


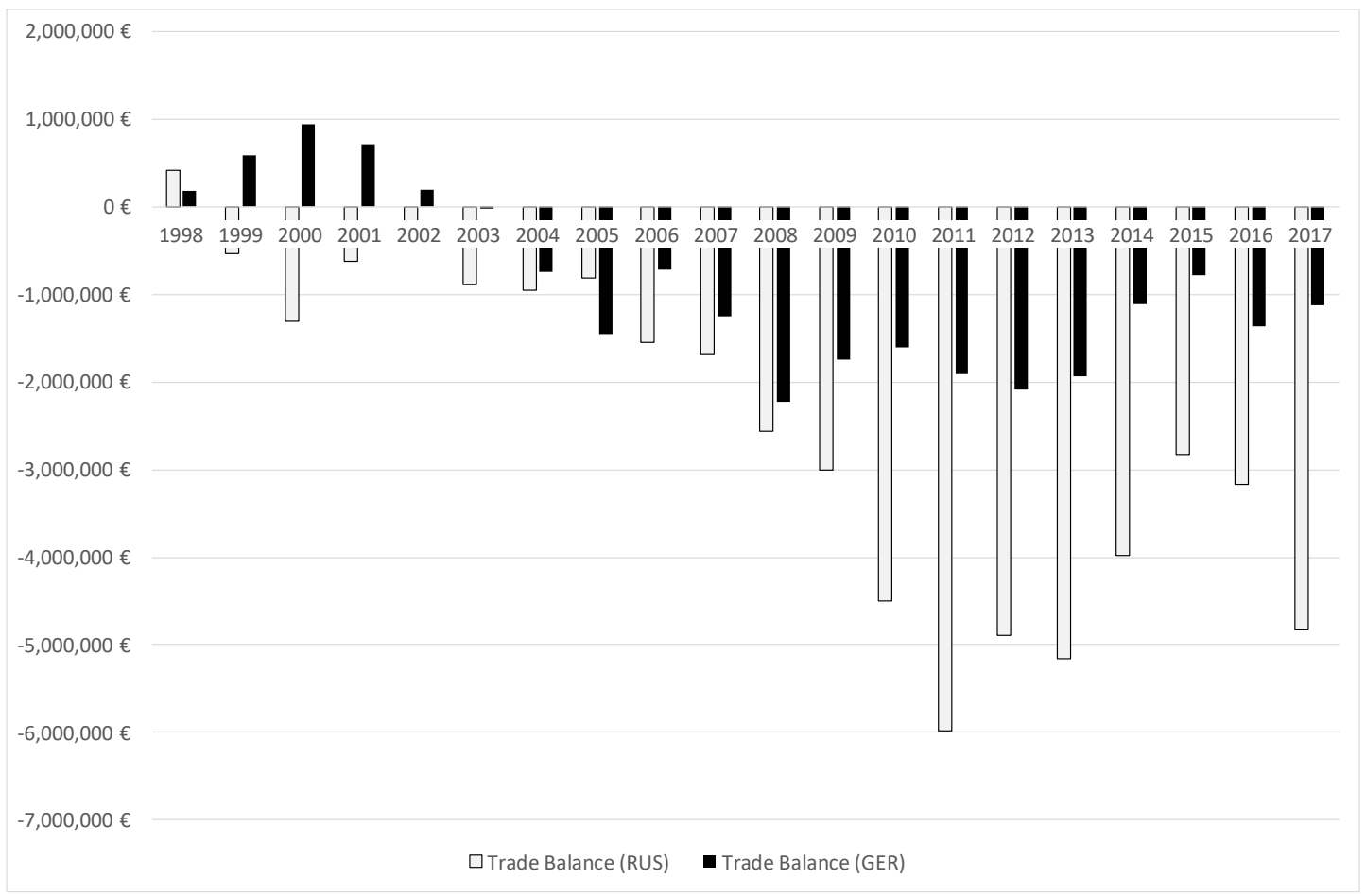

Figure 3. Finnish balance of trade (in '000 EUR) with Russia (RUS) and Germany (GER) during the period of 1998-2017. Source (data): Finnish Customs (2018)

Based on this all background information, it is not surprising to find out from Figure 4 that current unitized cargo volumes between Finland and Germany are actually in 2017 still below best years of 20072008 (12.4\% lower than in 2007). There have been clear and consistent recovery from the lows of 2009, but in years 2016-2017 this recovery has changed itself as at least to mid-term decline. However, in longterm volumes are still on growth trajectory - they are $52 \%$ higher than in 1998.

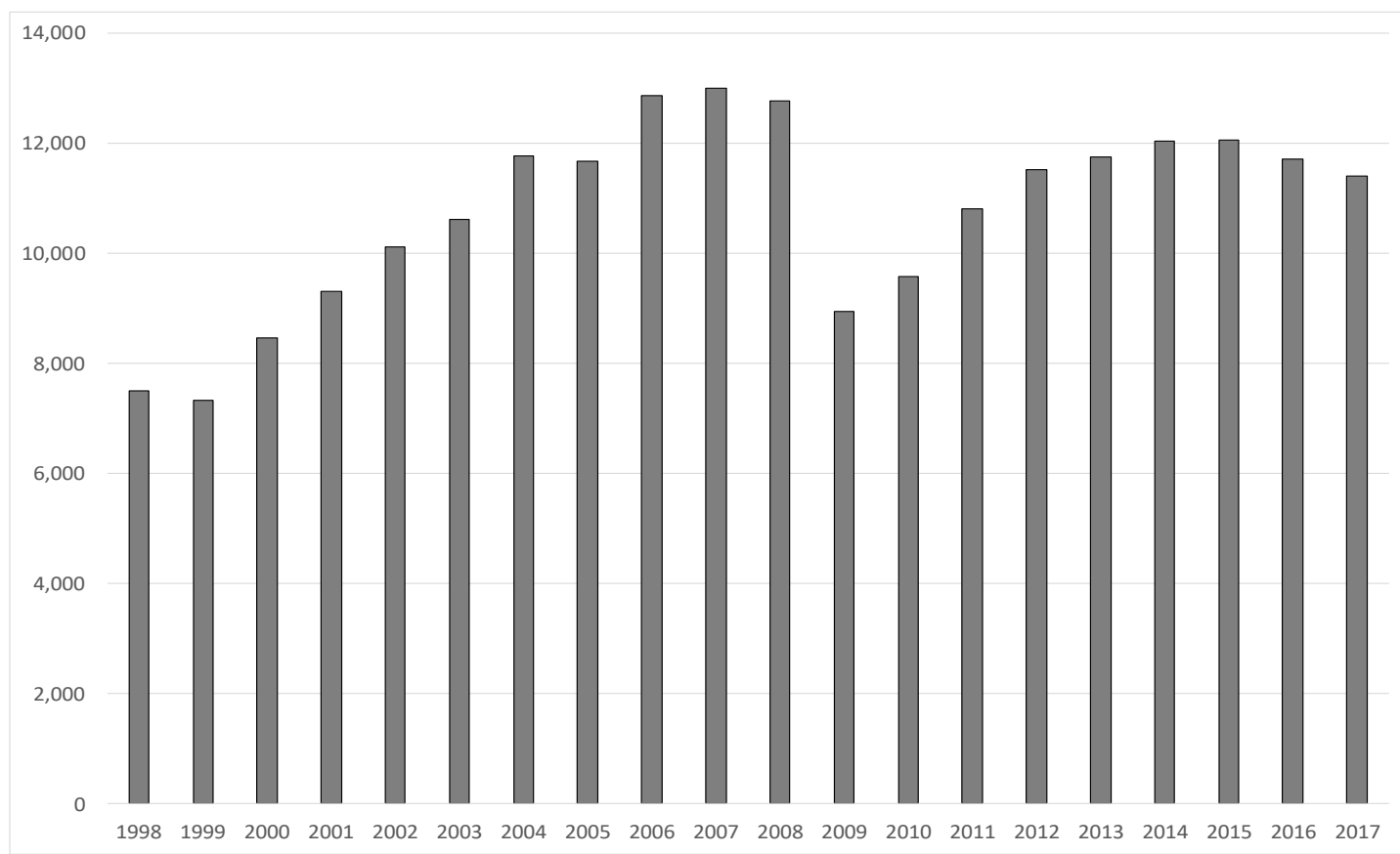

Figure 4. Unitized maritime freight volume ('000 tons) between Finland and Germany during the years 1998-2017. Source (data): Eurostat (2018), Finnish Transport Agency (2018) 
Unitized German maritime freight is split to many different ports in Finland. Most important sea ports of Helsinki, HaminaKotka, Hanko and Rauma take approx. $80 \%$ from overall tonnage handling (in good year, this share could be well above $80 \%$ ). First three mentioned have basically sustained in volumes and replicating more or less overall demand (Fig. 5). However, their long-term growth (in years 2001-2017) is conservative, ranging from somewhat above $10 \%$ (HaminaKotka \& Helsinki) to nearly 30 $\%$ (Hanko). Best year was 2007 in Helsinki and 2006 in HaminaKotka - in the last observation years volumes are down $23.9 \%$ and $48.7 \%$ from these high points. In the situation of HaminaKotka, booming transit import of Russia was the reason for such high volumes in 2006. Third sea port, Hanko has had basically two nearly equal volume high volume periods, where first one was in 2005, and latter in 2015. Sea port in the first mentioned period benefitted from Russian transit imports, and in the latter it was caused by shifts of ships to serve German traffic through this sea port as sulphur regulation stepped in and sea port offered a bit shorter sea journey than others.



Figure 5. Unitized maritime freight volume ('000 tons) of three major Finnish sea ports with Germany during the years 2001-2017. Source (data): Eurostat (2018), Finnish Transport Agency (2018)

Not all sea ports follow the overall market trend. In Figure 6 is shown the performance of losing sea ports, namely Turku and Pori. Both of these were significant actors in the German unitized maritime flows in 2001, however, in 2017 volumes to Germany were approx. $80 \%$ lower in both ports. In contrary within Figure 7, sea ports of Rauma and Uusikaupunki have done extremely well in long-term (20012017 ) - both of these have recorded handling volume growth of around $200 \%$. Reasons differ between these two. Rauma became important container sea port during this period and is the third largest in Finland. Uusikaupunki in turn is having car assembly factory (subcontracting for big car brands), which has been going through good volume growth in 2014-2017. However, as can be noted, volumes at car assembly within high cost country can vary. Sea port was having really low volume in 2008-2012. 


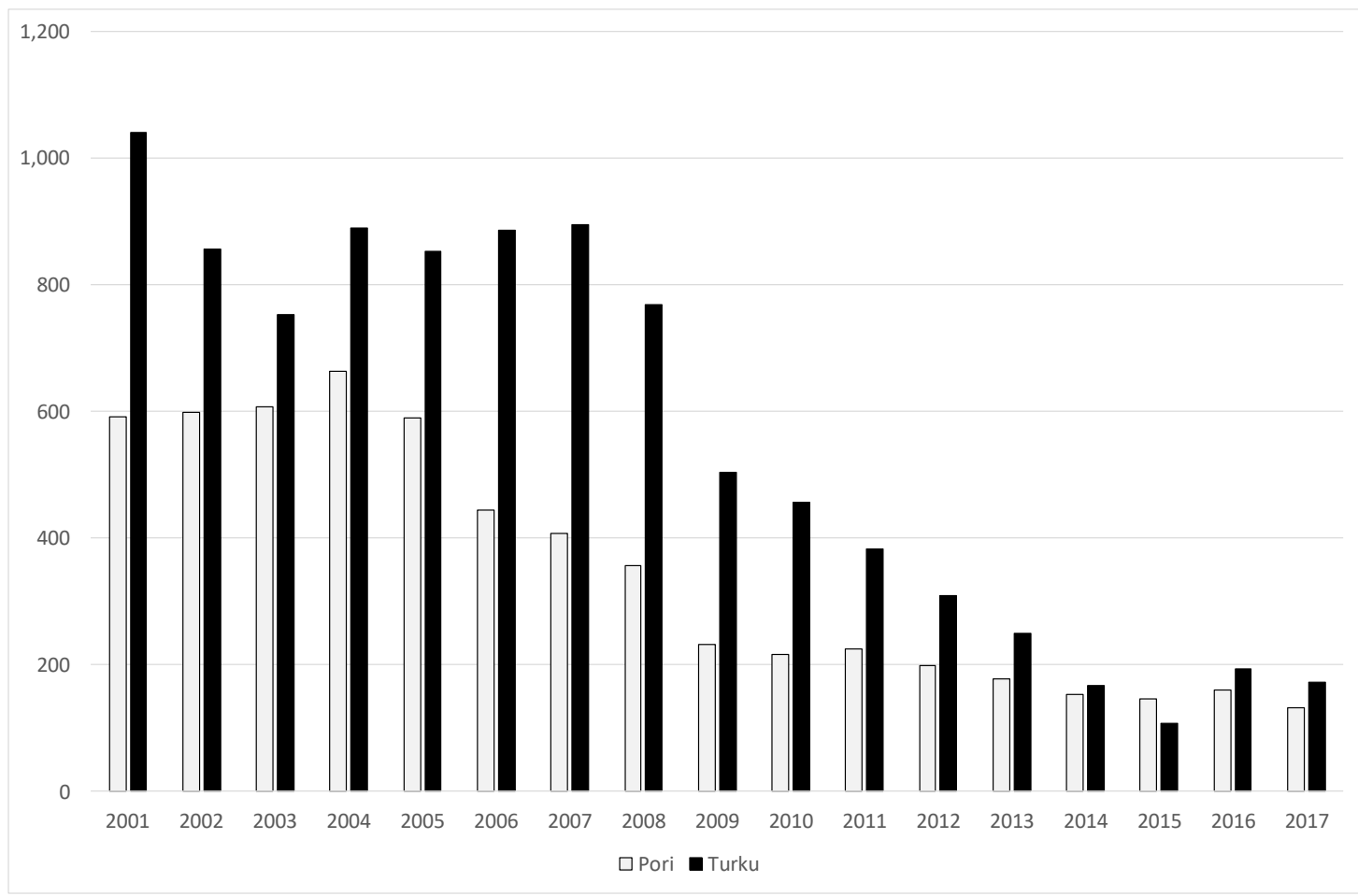

Figure 6. Unitized maritime freight volume ('000 tons) of two Finnish sea ports with Germany during the years 2001-2017 - both having declining performance. Source (data): Eurostat (2018), Finnish Transport Agency (2018)



Figure 7. Unitized maritime freight volume ('000 tons) of two Finnish sea ports with Germany during the years 2001-2017 - both having improving performance. Source (data): Eurostat (2018), Finnish Transport Agency (2018) 
Two more longer distant and lower volume sea ports are shown in Figure 8. In long-term (20012017) their unitized freight with Germany has increased substantially - port of Kemi was having such low volume in the base year that its growth has been $460.9 \%$, while port of Oulu has shown growth of 237.4 $\%$. However, most of this growth took place before GFC, and thereafter development has been on sideways. In 2015, both of these sea ports experienced some sort of upswing in unitized flows, however, this was caused mostly with the shipping company providing service to Baltic Sea ports of Germany, instead of Sweden and longer distance sea ports of Göteborg. Increases in freight volumes in 2015, however, are not in the extent, how much was lost in Swedish flows. So, these Swedish connection trucks are now also in other routes, and basically using more hinterland transports.

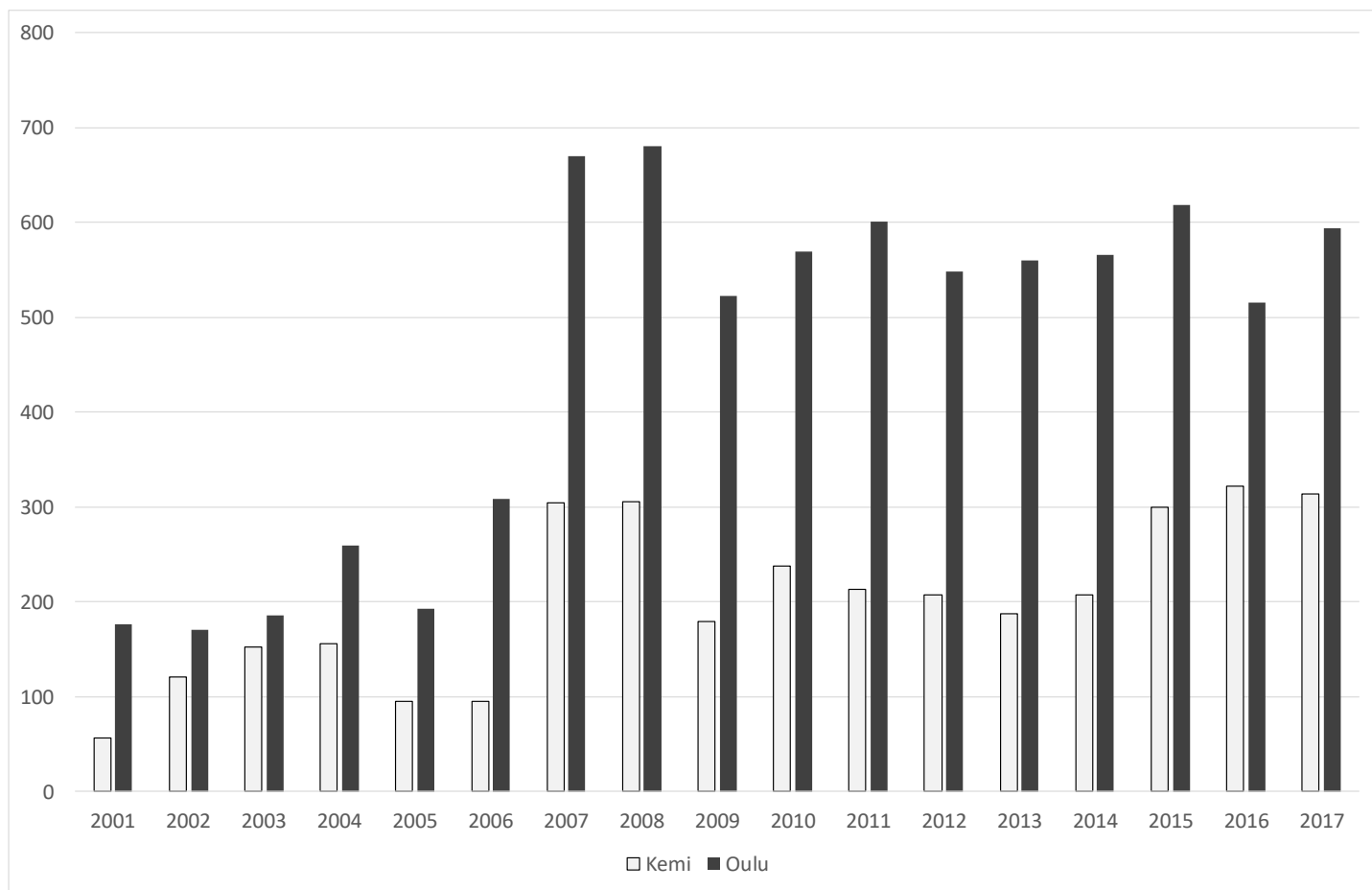

Figure 8. Unitized maritime freight volume ('000 tons) of two longer distant Finnish sea ports with Germany during the years 2001-2017.

Source (data): Eurostat (2018), Finnish Transport Agency (2018)

\section{Conclusions}

Economic and trade growth is interesting issue, and most often associated directly with growing volumes of logistics and supply chains. However, as this research illustrated, growth of unitized maritime cargo flows has faced difficulties after GFC between Germany and Finland. Only two mid-sized sea ports have shown clear and strong growth during the period of 2001-2017, however, one of these two was having very low multi-year time period of extremely low volume during these years. In the bigger sea ports unitized cargo has not grown, and in many cases it is still below best years of pre-crisis time. On the other end, two mid-sized sea ports have lost a lot of sea port handling volume in unitized segment, around $80 \%$ lower in 2017 than in the early years of examination period. Thus, it should be noted that trade performance has not been that poor as foreign trade between analysed countries has all the time increased and is clearly above GFC levels.

One explanation for lower volumes is the price inflation - even if trade values increase, they are doing so mostly due to higher prices rather than higher volumes. This could not be known with high accuracy, since products could be transported between Germany and Finland using other than direct short-sea shipping route between the countries (e.g. alternatively through Baltic States and Poland, or through Swedish route using either Danish hinterland or very southern short-sea shipping routes). Maybe answer is combination of both of these factors. Price inflation has been affecting the results, but also other 
routes have been used. Most popular has been Baltic States and Polish based route as it has offered competitive price as compared to shipping costs in post 2015 world (sulphur regulation). This route has also been handy for many companies as they have operations e.g. in Poland, to combine shipments for customers as final total delivery.

As further research in this topic, it would be interesting to examine development of Baltic States, and particularly Latvia and Estonia in the same manner, what was done in this study. They are of course smaller economies as compared to Finland, but their trade relationship and logistics solutions are rather similar with Germany. Only difference is that hinterland transportation alternative is much more attractive (as there does not necessarily exist any need for sea transportation component using trucks) with Germany.

\section{References}

1. DB-Schenker (2018) Deutsche Bahn 2017 Integrated Report. Berlin, Germany.

2. De Langen, P., Udenio, M., Fransoo, J.C., Helminen R. (2016) Port connectivity indices: an application to European RoRo shipping. Journal of Shipping and Trade, 1:6. https://doi.org/10.1186/s41072-016-0008-0

3. DHL (2018) 2017 Annual Report. Bonn, Germany.

4. Ellyatt, H. (2018) Germany's massive trade surplus 'is becoming toxic,' Ifo director says. CNBC, 4.July.2018. Available at URL - https://www.cnbc.com/2018/07/04/germanys-massive-trade-surplusis-becoming-toxic-ifo-director-says.html (Retrieved: 22.Oct. 2018)

5. Eurostat (2018) Maritime transport - goods - detailed annual and quarterly results. Available at URL - https://ec.europa.eu/eurostat/web/transport/data/database\# (Retrieved: 11.Sept. 2018)

6. Finnish Customs (2018) Country Statistics. Available at URL - https://tulli.fi/en/statistics/countrystatistics (Retrieved: 14.Sept. 2018)

7. Finnish Transport Agency (2018) Detailed maritime statistics concerning foreign flows (given by request). (Retrieved: Feb. 2018)

8. Heilmann, S., Wolff, G.B. (2018) Germany's export-oriented economic model is caught in a USChinese squeeze. Available at URL - http://bruegel.org/2018/04/germany-export-oriented-economicmodel-us-chinese-squeeze (Retrieved: 22.Oct. 2018)

9. Hilmola, O-P. (2014) Labile Fiat Currencies: Sketch of Future Alternatives. In Mention\&Torkkeli: Innovation in Financial Services: A Dual Ambiguity. Cambridge Scholars Publishing, UK, pp.12-31.

10. Hilmola, O-P. (2019) The Sulphur Cap in Maritime Supply Chains: Environmental Regulations in European Logistics. Palgrave Macmillan, Pivot Series. UK.

11. IMO (2018) Sulphur oxides (SOx) and Particulate Matter (PM) - Regulation 14. Available at URL http://www.imo.org/en/OurWork/Environment/PollutionPrevention/AirPollution/Pages/Sulphuroxides-(SOx)-\%E2\%80\%93-Regulation-14.aspx (Retrieved: 19.Feb. 2018)

12. Lapavitsas, C., Kaltenbrunner, A., Labrinidis, G., Lindo, D., Meadway, J., Michell, J., Painceira, J.P., Pires, E., Powell, J., Stenfors, A., Teles, N. and Vatikiotis, L. (2012) Crisis in the Eurozone. Verso: London, New York.

13. Lindstad, H.E., Rehn, C.F. and Eskeland, G.S. (2017) Sulphur abatement globally in maritime shipping. Transportation Research Part D, 57, pp. 303-313.

14. Liu, Q. (2010) Efficiency Analysis of Container Ports and Terminals. Doctoral Thesis, University College London.

15. Rashidi, H. and Tsang, E. (2016) Vehicle Scheduling in Port Automation: Advanced Algorithms for Minimum Cost Flow Problems. CRC Press, Taylor \& Francis: Boca Raton, USA. Second edition, pp. 2-5. ISBN 978-1-4987-3253-6

16. Reuters (2018a) Germany's trade surplus shrinks for first time since 2009. Available at URL https:/www.reuters.com/article/us-germany-economy-trade/germanys-trade-surplus-shrinks-for-firsttime-since-2009-idUSKBN1FS0VD (Retrieved: 5.Oct. 2018)

17. Reuters (2018b) Lufthansa regains place as Europe's biggest airline from Ryanair. Reuters, 10.January, 2018. Available at URL - https://www.reuters.com/article/lufthansa-traffic/lufthansaregains-place-as-europes-biggest-airline-from-ryanair-idUSL8N1OK2LR (Retrieved: 24.Sept. 2018)

18. Rickards, J. (2012) Currency Wars - the making of the next global crisis. Penguin Books, New York. USA.

19. Stiglitz, J.E. (2018) The Euro: How Common Currency Threatens the Future of Europe. First Edition. W. W. Norton \& Company, London, UK. 
20. United Nations (2018) Review of Maritime Transport. United Nations Conference on Trade and Development, New York. Available at URL - https://unctad.org/en/Pages/Publications/Review-ofMaritime-Transport-(Series).aspx (Retrieved: Oct. 2018)

21. Varoufakis, Y. (2016) And the Weak Suffer What They Must? Vintage, Penguin Random House, London, UK.

22. World Bank (2018) World Development Indicators - GDP Growth (annual \%). Available at URL https://data.worldbank.org/indicator/ny.gdp.mktp.kd.zg (Retrieved: 28.Aug. 2018) 